\title{
Effects of Providing Water from a Bucket or a Nipple on the Performance and Behavior of Calves Fed Ad Libitum Volumes of Acidified Milk Replacer
}

\author{
H. P. Hepola, ${ }^{11,2}$ L. T. Hänninen, $t^{1}$ S. M. Raussi, $\neq^{1}$ P. A. Pursiainen, ${ }^{\star}$ A.-M. Aarnikoivu, ${ }^{\star}$ \\ and $H$. S. Saloniemi ${ }^{1}$ \\ *Department of Animal Science, PO Box 28, 00014 University of Helsinki, Finland \\ †Department of Production Animal Medicine, PO Box 57, 00014 University of Helsinki, Finland \\ †MTT Agrifood Research Finland, Animal Production Research, 31600 Jokioinen, Finland
}

\begin{abstract}
Little information is available on how much water ad libitum milk-fed calves consume during the milk-feeding stage and during weaning to solid feed. Further, no information exists on the effects on calf behavior and performance of different water delivery systems during these stages. Therefore, the objectives of this study were first, to examine the water intake of calves fed acidified milk replacer ad libitum during the milk-feeding and weaning stages, and second, to determine whether the method of water delivery affected water and feed intake and growth during these periods or oral behavior during weaning. To evaluate this, we registered feed and water intake, growth, and oral behaviors of 24 dairy calves before and after abrupt weaning from a 7-wk ad libitum acidified milk replacer feeding regimen. Two water sources (open bucket and nipple) were compared. During the 7-wk milk-feeding period, the calves drank, on average, $12.9 \pm 0.7 \mathrm{~L} / \mathrm{d}$ of acidified milk replacer but very little water. However, after abrupt removal of milk, the 2-mo-old calves rapidly increased their water intake. Moreover, no differences in water intake between the 2 water sources were noted either before or after abrupt weaning. Calves were observed to have some difficulties in using the water nipple. Calves provided water through the nipples consumed less water at each drinking bout but visited the water nipple more frequently compared with calves provided access to water from the bucket. We observed no differences in all other behaviors observed. Overall, the calves rapidly increased their feed intake, rumination time, frequency of cross-sucking, and vocalization after weaning. In conclusion, despite the calves' consuming very little water when provided ad libitum access to acidified milk replacer, they dramatically in-
\end{abstract}

Received September 4, 2007.

Accepted December 12, 2007.

${ }^{1}$ Belongs to the Research Centre for Animal Welfare.

${ }^{2}$ Corresponding author: helena.hepola@helsinki.fi creased their water consumption after abrupt weaning from milk. Calves did experience some difficulties in using the water nipples.

Key words: dairy calf, ad libitum milk feeding, water, behavior

\section{INTRODUCTION}

Water is essential in many biochemical processes in the body, playing a critical role in the regulation of body temperature and osmotic pressure (Davis and Drackley, 1998). Calves receive water from milk, from other feeds, and from free water. Water is also gained in the oxidation of food and body tissues. Water from the body is lost in feces, urine, sweat, and respiration. The water requirement for animals is affected by many factors, including environmental temperature and age, with young animals requiring more water per unit of body size than mature animals (Maynard et al., 1979). Dairy calves are typically fed a restricted amount of milk or milk replacer, with the common daily recommendation being 8 to $10 \%$ of BW (Drackley, 2005). Restrictively milk-fed calves receiving water ad libitum eat more concentrates than calves not receiving water (Kertz et al., 1984).

Calves grow more with increased milk intake (Flower and Weary, 2001; Jasper and Weary, 2002), and recent work also suggests that they may benefit later in life from receiving higher milk volumes early in life (e.g., reviews by Tanan and Newbold, 2002; Drackley, 2005). However, weaning from high milk allowances may decrease calves' growth after weaning (Bar-Peled et al., 1997; Härtel et al., 2002). Consequently, different weaning methods from high milk allowances have recently received considerable interest (Jensen, 2006; Khan et al., 2007a,b). However, little information is available on how much water calves fed milk ad libitum consume during the milk-feeding stage and during weaning to solid feed. Calves provided ad libitum milk diets may in fact not consume substantial amounts of water. However, water in milk or milk replacer goes directly to the 


\begin{tabular}{|c|c|c|c|c|c|c|c|c|c|c|c|}
\hline \multirow[t]{3}{*}{ Alley } & $\begin{array}{l}\text { BUCKET } \\
1\end{array}$ & & $\begin{array}{l}\text { NIPPLE } \\
2\end{array}$ & & \multirow{3}{*}{\multicolumn{2}{|c|}{ Alley }} & \multicolumn{2}{|l|}{$\begin{array}{l}\text { NIPPLE } \\
7\end{array}$} & \multicolumn{2}{|l|}{$\begin{array}{l}\text { BUCKET } \\
8\end{array}$} & \multirow[t]{3}{*}{ Alley } \\
\hline & $\begin{array}{l}\text { BUCKET } \\
3\end{array}$ & & $\begin{array}{l}\text { NIPPLE } \\
4\end{array}$ & & & & \multicolumn{2}{|l|}{$\begin{array}{l}\text { NIPPLE } \\
9\end{array}$} & \multicolumn{2}{|l|}{$\begin{array}{l}\text { BUCKET } \\
10\end{array}$} & \\
\hline & $\begin{array}{l}\text { BUCKET } \\
5\end{array}$ & & $\begin{array}{l}\text { NIPPLE } \\
6\end{array}$ & & & & \multicolumn{2}{|l|}{$\begin{array}{l}\text { NIPPLE } \\
11\end{array}$} & \multicolumn{2}{|l|}{$\begin{array}{l}\text { BUCKET } \\
12\end{array}$} & \\
\hline \multicolumn{12}{|l|}{ Alley } \\
\hline Yard & & Yard & & Yard & & Yard & & Yard & & Yard & \\
\hline $1+2$ & & $3+4$ & & $5+6$ & & $7+8$ & & $9+10$ & & $11+12$ & \\
\hline
\end{tabular}

Figure 1. A schematic picture of the experimental room for one replicate.

abomasum (Ørskov, 1972). The rumen microbes live in a moist environment (Yokoyama and Johnson, 1988), and recent work has suggested that additional water may affect the development of rumen papillae in veal calves receiving straw (Gottardo et al., 2002).

Water nipples might be a more hygienic water source for young stock, but no information exists about different water sources for calves in terms of water intake, calf behavior, and performance before and after weaning from milk. Adult cows prefer to use larger troughs instead of smaller ones (Machado Filho et al., 2004; Teixeira et al., 2006). We hypothesized that calves also prefer an open water source and drink more water from an open bucket than from a water nipple.

Hunger during weaning can predispose calves to more cross-sucking (Jensen, 2003), and hungry calves also vocalize more than adequately fed ones (Thomas et al., 2001). We also examined whether the DMI, oral behavior, and number of vocalizations during weaning were affected by the method of water delivery. The objectives of this experiment were to examine the effects of providing water through an open bucket or nipple on the water and DMI, growth, and behavior of dairy calves provided ad libitum acidified milk replacer and then abruptly weaned to solid feed.

\section{MATERIALS AND METHODS}

This experiment was performed at the Viikki Experimental Farm of the University of Helsinki, Finland. The study protocol was approved by the Ethics Committee for the use of experimental animals at the University of Helsinki.

\section{Animals and Housing}

Twenty-four calves were born at the experimental farm of the University of Helsinki. The calves were paired according to birth date and allotted to 1 of the 2 water source treatments: an open bucket (bucket) or a water nipple (nipple). The experiment was organized in 2 replicates, with 12 calves in each, between September 2004 and March 2005. The experiment began when the youngest calf in the pair was $7 \mathrm{~d}$ old and the oldest one was a maximum of $12 \mathrm{~d}$. The mean age of the calves at the beginning of the experiment was $7.9( \pm 0.5) \mathrm{d}$ for the bucket group and $7.7( \pm 0.4) \mathrm{d}$ for the nipple group, and their respective live weights were $48.2( \pm 2.1) \mathrm{kg}$ and 48.4 $( \pm 2.5) \mathrm{kg}$. In the bucket group, 6 of the calves were male and 6 were female, and in the nipple group 8 were male and 4 were female. Two of the male calves in both groups were of the Holstein-Friesian breed; all other calves were Ayrshires. The experiment lasted for $9 \mathrm{wk}$.

Before the experiment started, the newborn calves were kept with their dams for 12 to $24 \mathrm{~h}$ in a parturition pen. Calves were then housed individually in pens with slatted wooden floors that were $1.0 \times 1.2 \mathrm{~m}$ and bedded with straw. The calves could see and touch each other through the openings in the upper part of the pen wall.

After colostrum feeding, the calves were moved to another building for the experiment, where they were housed individually in $1.5 \times 1.2 \mathrm{~m}$ solid-floor pens bedded with a turf-sawdust mixture. The calves could have some body contact with neighboring calves over the $93-\mathrm{cm}$ high pen walls. A $20 \times 45 \mathrm{~cm}$ hole in the back wall of the pen permitted additional contact between a calf pair. Moreover, every day from 0900 to $1100 \mathrm{~h}$, when the pens were cleaned, the calf pair was released to a separate yard $(1.2 \times 3.0 \mathrm{~m})$ with solid partitions between yards (107 cm high). The yard was littered with wood shavings, but no feed or water was offered. Oral behavior during weaning was observed during this time. The calf pairs were guided from the yard to their home pens in the same order as they were guided into the yard. The lights were on from 0700 to $2100 \mathrm{~h}$, and a dim night-light permitted video recordings. Natural light also came in through the windows. The room was ventilated with 
Table 1. Definitions for recorded behaviors

\begin{tabular}{ll}
\hline Behavior & Definition \\
\hline Licking structures ${ }^{1}$ & Calf's tongue touching any part of pen structures \\
Licking oneself $^{1}$ & Calf licking any part of itself \\
Licking another calf $^{1}$ & Calf's tongue touching any part of another calf \\
Cross-sucking $^{1}$ & Calf sucking ear, belly, navel, genitals, or any other part of another calf \\
Tongue rolling $^{1}$ & Calf rolling its tongue either inside or outside the mouth \\
Drinking milk & Calf having teat in its mouth \\
Drinking water & Calf having head in a water bucket or in a bucket for dripped water, \\
& or having the water nipple in its mouth, or pressing the water nipple \\
& with its forehead. \\
Eating hay $^{2}$ & Calf having hay in its mouth or head in the hay trough \\
Eating concentrate $^{2}$ & Calf having head in the concentrate trough \\
Ruminating $^{2}$ & Repetitive movements of lower jaw in the lateral plane \\
Vocalization $^{2}$ & Calf keeping its head stretched upward and mouth open \\
\hline${ }^{1}$ Behaviors observed directly. &
\end{tabular}

electric fans, and the average room temperature during the first replicate was $+19^{\circ} \mathrm{C}$ (range +13.5 to $+22^{\circ} \mathrm{C}$ ) and during the second replicate was $+18^{\circ} \mathrm{C}$ (range +15 to $+21^{\circ} \mathrm{C}$ ). The experimental room and treatment allocation in the room are shown in Figure 1.

\section{Feeding}

Calves had free access to water. Before the experiment, the calves had access to the same water source (open bucket or water nipple) as during their treatment. On the first experimental day, the calves were taught twice to use the water source by guiding each calf gently to the water source and dribbling water droplets into its mouth. Calves in the nipple group drank from water nipples, which had a mean stream velocity of $2 \mathrm{~L} / \mathrm{min}$. The water nipples were equipped with water meters that were read every morning at $0800 \mathrm{~h}$. In addition, a bucket was placed under the water nipple to collect dripping water. The water intake from nipples was calculated as the water run from the nipple minus the water in the bucket. Before the second replicate, a wooden barrier was added to prevent calves from drinking water from that bucket. Despite the barrier, calves still tried to reach the dripped water in the bucket below. Calves in the bucket group, in turn, drank from 10-L plastic water buckets. Water intake was measured daily throughout the experiment.

The calves were fed milk or milk replacer from teat buckets until weaning at the end of the seventh experimental week. The calves were initially given $2 \mathrm{~L}$ of colostrum from a teat bottle within $2 \mathrm{~h}$ postpartum. After this, they were allowed to suckle their dam in the parturition pen (12 to $24 \mathrm{~h}$ ). After the parturition pen, calves received $3 \mathrm{~L}$ of colostrum twice a day until $4 \mathrm{~d}$ of age. Between 4 and $14 \mathrm{~d}$ of age, calves were fed acidified whole milk ad libitum (20.0 MJ of ME, $265 \mathrm{~g}$ of CP, and
$315 \mathrm{~g}$ of crude fat $/ \mathrm{kg}$ of $\mathrm{DM}$ ), and on d 15 of the experiment they were switched to acidified milk replacer ad libitum (Suomen Rehu, Espoo, Finland, 16.7 MJ of ME, $232 \mathrm{~g}$ of $\mathrm{CP}$, and $168 \mathrm{~g}$ of crude fat $/ \mathrm{kg}$ of DM) and then weaned abruptly on $\mathrm{d} 51$ of the experiment (calf age 58 to $62 \mathrm{~d}$ ). The concentration of milk replacer was $125 \mathrm{~g}$ of powder/L of water. Whole milk was acidified to $\mathrm{pH}$ 4.5 (von Bothmer, 1992) and milk replacer to $\mathrm{pH} 5.0$ (according to the manufacturer's instructions) with formic acid-based feed preservative (Valio Ltd., Helsinki, Finland). During the experiment, the calves had individual 15-L teat buckets. Daily consumption was measured at $0700 \mathrm{~h}$. Fresh acidified milk or milk replacer was added at this time and then again at 1100, 1500, and $2100 \mathrm{~h}$. Sham adding of milk or milk replacer was performed for the calves that had full teat buckets. The teat buckets were cleaned daily at $0700 \mathrm{~h}$ by rinsing, and once a week the teats were removed and the buckets were washed thoroughly. Milk or milk replacer intake was measured daily during experimental wk 1 to 7 .

Calves received a daily maximum of $3 \mathrm{~kg}$ of concentrates (Suomen Rehu, 13.0 MJ of ME, $196 \mathrm{~g}$ of CP, 61 $\mathrm{g}$ of crude fat, and $247 \mathrm{~g}$ of NDF/ $\mathrm{kg}$ of DM). Concentrate intake was measured weekly during experimental wk 4 to 7 and 9, and daily during experimental wk 8. Hay was offered ad libitum (10.6 MJ of ME, $146 \mathrm{~g}$ of CP, and $543 \mathrm{~g}$ of $\mathrm{NDF} / \mathrm{kg}$ of DM). Hay intake was measured weekly during experimental wk 4 to 9 .

The calves were weighed at the beginning of the experiment on 2 consecutive days and then on the first day of every week until they were abruptly weaned. At weaning, they were weighed on 2 consecutive days and then daily for 1 wk after weaning, and at the end of the experiment they were again weighed on 2 consecutive days. When calves were weighed on 2 consecutive days, the average of these measurements was used in the results. The growth check after weaning was measured 
Table 2. Feed and water intake and growth of calves before and after weaning off ad libitum acidified milk replacer ${ }^{1}$

\begin{tabular}{|c|c|c|c|c|c|c|c|c|c|}
\hline \multirow[b]{3}{*}{ Treatment } & \multirow{2}{*}{\multicolumn{2}{|c|}{$\begin{array}{c}\text { Period } 1,{ }^{2} \\
\text { before weaning }\end{array}$}} & \multirow[b]{3}{*}{ SEM } & \multirow{2}{*}{\multicolumn{2}{|c|}{$\begin{array}{c}\text { Period } 2{ }^{2} \\
\text { after weaning }\end{array}$}} & \multirow[b]{3}{*}{ SEM } & \multicolumn{2}{|c|}{ Main effect } & \multirow{3}{*}{$\begin{array}{l}\text { Interaction } \\
\text { of treatment } \times \\
\text { period, } P\end{array}$} \\
\hline & & & & & & & Treatment. & Period. & \\
\hline & Bucket & Nipple & & Bucket & Nipple & & $P$ & $P$ & \\
\hline Milk, $\mathrm{kg}$ of DM/d & 1.32 & 1.39 & 0.06 & - & - & - & 0.47 & - & - \\
\hline Water, kg/d & 0.36 & 0.35 & $0.10^{3}$ & 8.10 & 8.97 & $0.52^{4}$ & 0.26 & $<0.001$ & 0.28 \\
\hline Concentrates, $\mathrm{kg}$ of $\mathrm{DM} / \mathrm{d}$ & 0.15 & 0.17 & 0.03 & 1.74 & 1.62 & 0.11 & 0.60 & $<0.001$ & 0.37 \\
\hline Energy intake, MJ of ME/d & 27.4 & 28.4 & 0.9 & 28.4 & 26.9 & 1.5 & 0.86 & 0.83 & 0.34 \\
\hline Protein intake, $\mathrm{AAT}^{5}, \mathrm{~g} / \mathrm{d}$ & 309 & 317 & 12 & 254 & 241 & 13 & 0.81 & $<0.001$ & 0.46 \\
\hline Growth, kg/d & 1.09 & 1.15 & 0.05 & 0.93 & 0.80 & 0.11 & 0.63 & 0.02 & 0.37 \\
\hline Growth, $\mathrm{kg} / \mathrm{kg}$ of $\mathrm{DM}$ & 0.67 & 0.65 & 0.03 & 0.39 & 0.35 & 0.05 & 0.20 & $<0.001$ & 0.74 \\
\hline Growth, $\mathrm{kg} / \mathrm{MJ}$ of $\mathrm{ME}$ & 0.042 & 0.041 & 0.002 & 0.031 & 0.028 & 0.004 & 0.29 & 0.002 & 0.68 \\
\hline
\end{tabular}

${ }^{1}$ The calves received water either from an open bucket (bucket group) or from a nipple (nipple group).

${ }^{2}$ Period 1: Milk, water, and growth measured during experimental wk 1 to 7, hay and concentrates during experimental wk 4 to 7 . Total feed intake and feed efficiency (gain to feed) calculated for experimental wk 4 to 7. Period 2: experimental wk 8 and 9.

${ }^{3}$ Nipple SEM $=1.05$ SEM.

${ }^{4}$ Nipple SEM $=1.04$ SEM.

${ }^{5} \mathrm{AAT}=\mathrm{AA}$ absorbable from the small intestine.

as the difference in the daily weights taken at weaning and 1 wk after weaning. All weighings were performed at the same time of day, that is, at $0900 \mathrm{~h}$, before the calves were directed to the separate yard. Feed efficiency was calculated as weight gain divided by DMI or ME intake.

\section{Feed Analyses}

A sample of milk replacer was taken whenever a new milk replacer sack was opened. Samples from concentrate sacks were taken at the beginning of the experiment. For analyses, milk replacer and concentrate samples were pooled to form one sample representing the entire experimental period. Hay was sampled weekly when hay portions were weighed, and the samples were pooled to form one analysis sample per month. Primary DM concentration of hay was determined monthly. Milk was analyzed for fat, protein, and lactose by infrared analysis (MilkoScan FT6000, Foss Electric, Hillerød, Denmark). The chemical compositions of milk replacer, concentrate, and hay samples were analyzed by using AOAC (1995) method 942.05 for ash, method 920.39 for ether extract (after $\mathrm{HCl}$ hydrolysis), and method 984.13 for $\mathrm{CP}$ analyses. Neutral detergent fiber was analyzed according to Van Soest et al. (1991). Energy (MJ of ME) and protein (AAT $=\mathrm{AA}$ absorbable from the small intestine) values of feeds were calculated according to Finnish feed tables (MTT, 2006).

\section{Health Recording}

The health of calves was observed daily. Fecal consistency was scored on a 2-point subjective scale routinely used by the caretakers at the experimental farm: normal (solid or normal loose feces), and diarrheic (loose or watery feces). Veterinary treatments were given when needed.

\section{Behavioral Recording}

Calves' oral behavior was observed in 2 ways. First, to examine oral behavior during weaning (licking oneself, licking another calf, licking structures, cross-sucking, and tongue rolling) calves (calf pairs) were observed directly in the yard from 0900 to $1100 \mathrm{~h} 2$ days before and $1 \mathrm{~d}$ after weaning ( -2 and $+1 \mathrm{~d}$, respectively). One observer at a time recorded one calf pair for the whole 2-h observation period. Definitions of observed oral behaviors are presented in Table 1.

Second, drinking, eating, ruminating, and vocalization before and after weaning were observed continuously for $24 \mathrm{~h}$ for each calf in individual pens. Definitions of these behaviors are presented in Table 1. Video recordings in 24-h mode were taken -1, 0 (day of weaning), $+1,+2$, and $+7 \mathrm{~d}$ relative to weaning. Ten cameras were installed on the ceiling; each camera recorded the behavior of 1 or 2 calves. Five cameras were connected to one multiplexer (MPX-CD92P, Sanyo, Osaka, Japan) and VHS (AG 6730, Panasonic, Osaka, Japan). Total daily duration, bout frequency, and mean bout duration of all behaviors were encoded by Observer software (Noldus, Wageningen, the Netherlands).

A water-drinking bout was defined as having commenced when a calf put its head in a water bucket or a bucket for dripped water, took a water nipple into its mouth, or pressed the water nipple with its forehead. 


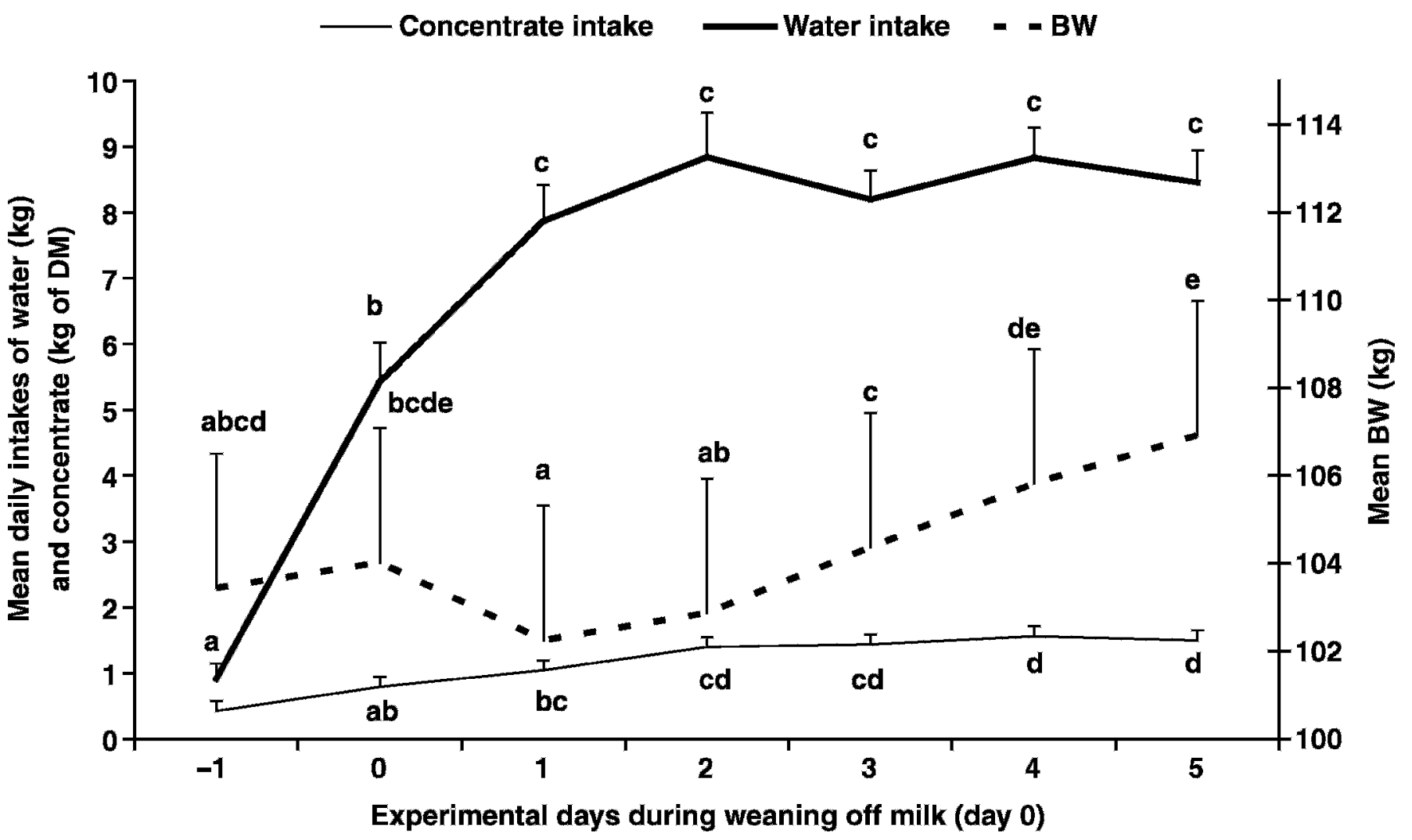

Figure 2. Mean water and concentrate intakes and BW of 2-mo-old calves before and after weaning off ad libitum acidified milk replacer. Error bars lacking a common letter differ $(P<0.05)$.

The water-drinking bout ended when the calf's head came out of the bucket or it released the nipple or stopped pressing the nipple with its forehead. Water-drinking bouts were merged when the difference between 2 consecutive bouts was $<30 \mathrm{~s}$ and the calf did nothing with its mouth during that interval.

Concentrate- or hay-eating bouts were defined as having commenced when a calf put its head in the concentrate or hay-feeding trough or clearly had hay in its mouth. The eating bout ended when the calf started to do something else with its mouth or did nothing with its mouth. A rumination bout was defined as having commenced when a calf made rumination movements with its jaws and was defined to have ended when these movements ceased.

\section{Statistics}

Results for mean individual water and feed intake as well as for growth data were calculated over 2 periods: 1) before weaning: 1 to $7 \mathrm{wk}$ for milk and water intake and growth, and 4 to $7 \mathrm{wk}$ for concentrate, hay, total DM, energy and protein intake, and feed efficiency; and
2) after weaning: 8 to $9 \mathrm{wk}$ for concentrate, hay, total DM, energy and protein intake, growth, and feed efficiency.

Water and feed intake and growth data were analyzed with a mixed model, taking repeated measures into account (SAS Institute Inc., Cary, NC). The fixed factors were treatment (bucket or nipple) and period (before and after weaning: 1 to $7 \mathrm{wk}$ or 4 to $7 \mathrm{wk}$ vs. 8 to $9 \mathrm{wk}$ ), and the treatment $\times$ period interaction; the pair (a pair consisted of 2 calves from different treatments) was a random effect. Birth weight and age of calves at the beginning of the experiment were used as covariates. Milk intake data were tested without a period effect. Normality of distribution was checked from the residuals. Homogeneity of variances was checked with a scatter plot of residuals and predicted values. Degrees of freedom were calculated by the Kenward-Roger method. Pearson correlation coefficients between water and feed intake during periods 4 to $7 \mathrm{wk}$ and 8 to $9 \mathrm{wk}$ were calculated for descriptive purposes. Water intake data were missing for 1 calf from the nipple group before weaning.

The effect of weaning on calves' water and concentrate intake and live weight change during the eighth week 


\section{Mean daily drinking frequency - Mean daily drinking bout duration}

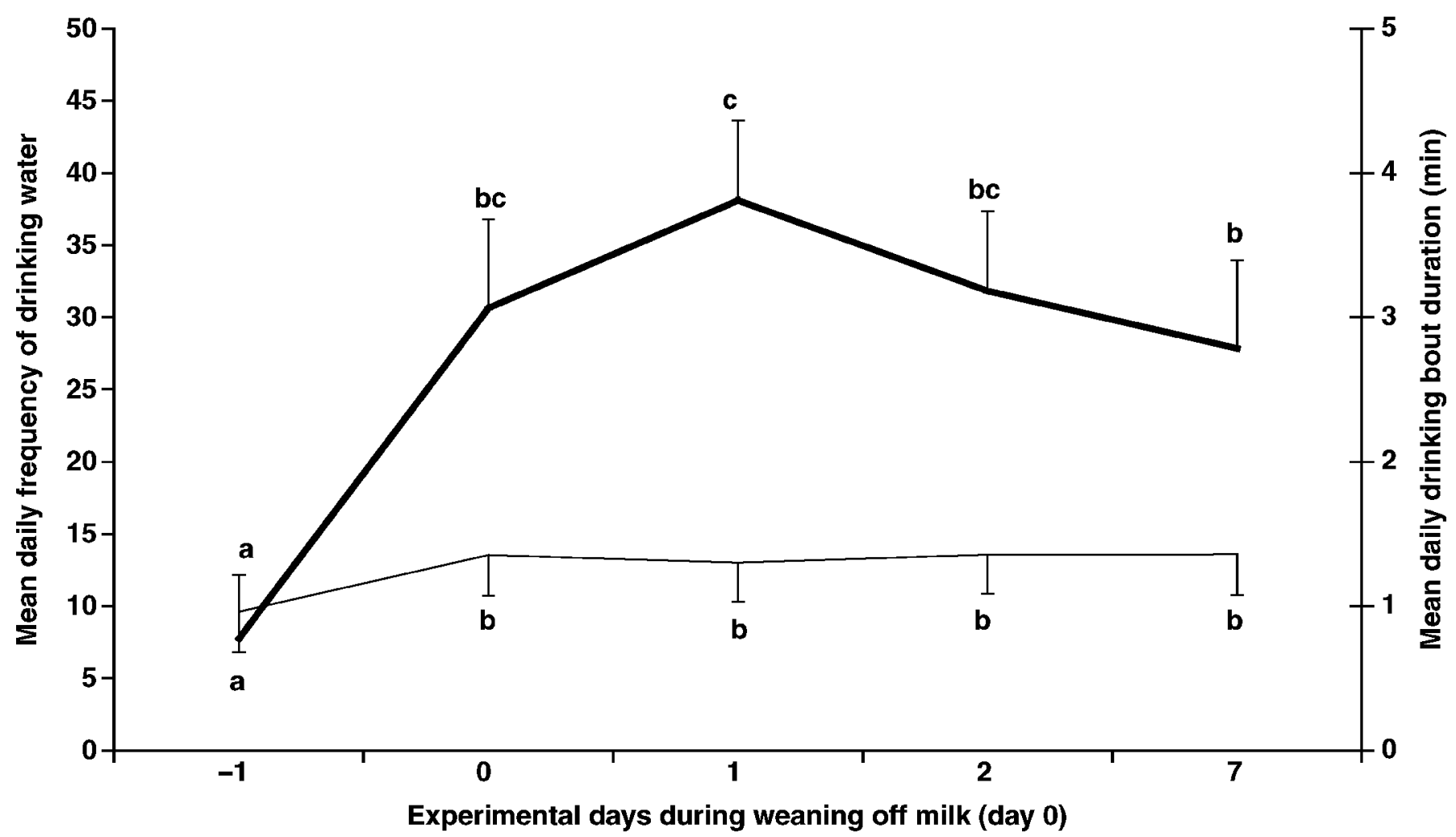

Figure 3. Mean daily frequency of drinking water and mean daily drinking bout duration of 2-mo-old calves before and after weaning off ad libitum acidified milk replacer. Error bars lacking a common letter differ $(P<0.05)$.

(daily intake and growth right before and after weaning) was tested with the same mixed model as above, but day was used as a fixed factor instead of period. The weight of calves during weaning was used as a covariate for concentrate and water intakes. The Tukey-Kramer test was used for post hoc comparisons between days.

Behavioral data both from video recording and from direct observations were tested for differences before and after weaning off milk with the same mixed model as the effect of weaning on intake and growth. No covariates were used. Data for cross-sucking was transformed, taking arcsine of the square root before the statistical analyses to meet the assumption of normal distribution of the data. Even after transformation, tongue-rolling data were not normally distributed. These data were therefore analyzed with a Friedman's 2-way nonparametric ANOVA separately before weaning and after weaning. Data from direct observations were not available for 1 calf pair because of technical problems with the recording device. Differences in prevalence of diarrhea (number of diarrhea days/all experimental days) between calves in the bucket and nipple groups were tested with a chi-squared test.
Statistical analyses were conducted with the SAS System for Windows, version 9.1 (2002-2003, SAS Institute Inc.). Results are expressed as least squares means \pm standard error. A $P$-value below 0.05 was considered statistically significant, with below 0.1 to indicate a tendency.

\section{RESULTS}

\section{Water and Feed Intake}

Calves fed acidified milk replacer ad libitum drank only small amounts of water (average $<0.4 \mathrm{~kg} / \mathrm{d}$ ) during the milk-feeding period, and no difference was observed between calves in the bucket and nipple groups $(P>0.1)$, nor did water intake differ after weaning between the 2 water sources $(P>0.1$; Table 2$)$. However, water intake increased rapidly within a few days of weaning. The average intake of water was $0.7 \pm 0.3 \mathrm{~L}$ for calves in the bucket group and $1.1 \pm 0.3 \mathrm{~L}$ for calves in the nipple group during the day before weaning, but the respective figures during the day after weaning were $7.5 \pm 0.7 \mathrm{~L}$ and $8.2 \pm 0.8 \mathrm{~L}$. No interaction existed between treat- 


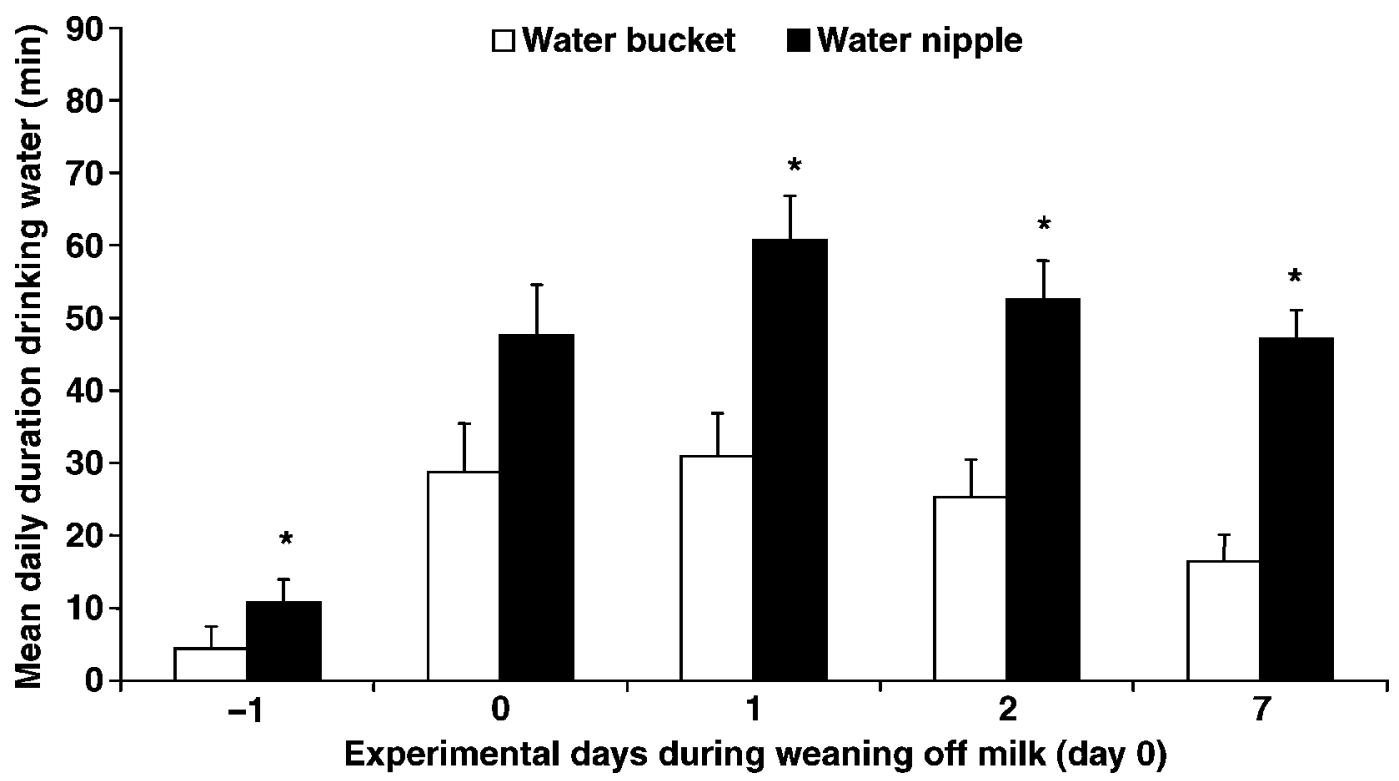

Figure 4. Total daily duration of drinking water of 2-mo-old calves before and after weaning off ad libitum acidified milk replacer. Asterisks mark significant difference $(P<0.05)$ between different water sources during different days.

ment and day; thus, data were pooled over the treatments to describe the trend in water intake during weaning (Figure 2).

Daily mean milk replacer intake during the milk-feeding period was $12.9 \pm 0.7 \mathrm{~kg}$. Milk intake increased from $8.6 \pm 0.6 \mathrm{~kg} / \mathrm{d}$ in the first experimental week to $14.0 \pm$ $0.7 \mathrm{~kg} / \mathrm{d}$ in the seventh experimental week, when the calves were approximately 8 wk old. Intakes of concentrate and hay were minimal during the 7 -wk milk-feeding period. No differences were observed between the 2 water sources either before or after weaning off milk ( $P$ $>0.1$; Table 2). Concentrate intake also increased rapidly after weaning (Figure 2), and there was no interaction between treatment and day. Before weaning, no correlation existed between water and concentrate intake, but after weaning, water and concentrate intakes correlated positively $(0.41, P=0.05)$.

\section{Growth and Feed Efficiency}

No differences were present in mean daily weight gain or feed efficiency between calves in the bucket and nipple groups before or after weaning (Table 2). Calves' BW decreased immediately after weaning $(P=0.004)$, but increased fairly quickly thereafter (Figure 2). No interaction existed between treatment and day. Feed efficiency was better before than after weaning $(P<0.1$; Table 2$)$.

\section{Health}

No significant differences were present in diarrhea prevalence between calves in the bucket and nipple groups before (1.8 vs. $0.9 \%$ ) or after weaning off milk $(1.5$ vs. $0.6 \%)$.

\section{Water Drinking and Other Oral Behaviors and Vocalization Before and After Weaning}

Although, the calves drank water less frequently from an open bucket than from a water nipple $(21 \pm 5$ and 34 \pm 6 , respectively, $P=0.02$ ), the treatment had no effect on the mean drinking bout duration $(1.1 \pm 0.3 \mathrm{~min}$ and $1.4 \pm 0.3 \mathrm{~min}$ from a water bucket and nipple, respectively). There was no interaction between the experimental days and treatments for total drinking frequency and mean drinking bout duration $(P>0.1)$. Both the number of drinking bouts $(P<0.001)$ and mean drinking bout duration $(P=0.03)$ increased after weaning (Figure 3$)$. The calves drank longer overall daily from a water nipple than from an open bucket $(43.6 \pm 2.8$ min vs. $21.1 \pm 2.8$ $\min , P<0.001$, respectively). However, there was an interaction between the treatments and days for the total daily drinking duration $(P<0.001)$; during the weaning day, the overall mean daily drinking duration did not differ between the treatments $(P>0.1$; Figure 4$)$.

Many calves used the water nipple in atypical ways; only $25 \%$ of the water-drinking bouts were directly from the nipple. The majority of the drinking bouts were performed differently, such as by pressing the water nipple with the forehead and drinking the dripping water.

Water source did not affect any of the observed behaviors before or after abrupt weaning from milk (Table 3). However, we registered several effects of weaning from 
Table 3. Oral behavior of 2-mo-old calves during weaning off ad libitum acidified milk replacer, \% of observations $^{1}$

\begin{tabular}{|c|c|c|c|c|c|c|c|c|c|}
\hline \multirow[b]{2}{*}{ Treatment } & \multicolumn{2}{|c|}{ Before weaning } & \multirow[b]{2}{*}{ SEM } & \multicolumn{2}{|c|}{ After weaning } & \multirow[b]{2}{*}{ SEM } & \multicolumn{2}{|c|}{ Main effect } & \multirow{2}{*}{$\begin{array}{l}\text { Interaction } \\
\text { treatment } \\
\times \text { day, } P\end{array}$} \\
\hline & Bucket & Nipple & & Bucket & Nipple & & Treatment, $P$ & Day, $P$ & \\
\hline Licking structures & 17.6 & 14.5 & 2.1 & 18.9 & 15.7 & 4.2 & 0.33 & 0.63 & 1.00 \\
\hline Licking oneself & 3.7 & 4.7 & 0.9 & 2.0 & 2.9 & 0.7 & 0.27 & 0.03 & 0.94 \\
\hline Licking another calf & 2.8 & 2.1 & 0.5 & 3.9 & 2.6 & 1.1 & 0.12 & 0.41 & 0.74 \\
\hline Cross-sucking & 0.8 & 1.5 & 0.8 & 10.5 & 9.4 & 3.0 & 0.89 & $<0.001$ & 0.37 \\
\hline
\end{tabular}

${ }^{1}$ The calves received water either from an open bucket (bucket group) or from a nipple (nipple group).

ad libitum acidified milk replacer on behavior. Calves' mean daily duration spent ruminating and eating solid feeds increased rapidly after weaning (Figure 5). In addition, calves licked themselves less after weaning than before weaning $(P<0.1)$, but cross-sucked (mainly sucked under another calf's belly) more after weaning than before weaning $(P<0.001$; Table 3$)$. Before weaning, tongue rolling was registered in 0.9 and $1.0 \%( \pm 0.4 \%)$ of observations for calves in the bucket and nipple groups, and after weaning in 2.0 and $0.3 \%( \pm 1.1 \%)$ of observations, respectively, but the differences were not statistically significant. In addition, during the first days after weaning, the calves vocalized more than before weaning, but we did find marked variation between calves (Figure 6).

\section{DISCUSSION}

Little information is available on how much water ad libitum milk-fed calves consume during the milk-feeding stage and during weaning to solid feed. Richard et al. (1988) reported water intake of calves fed acidified milk replacer ad libitum before weaning, and a recent experiment (von Keyserlingk et al., 2006) did look at the effects of providing water through a teat during non-milk-feeding times when calves were fed high volumes of milk. So far, there have been no studies about different water sources for calves in terms of water intake, calf behavior, and performance before and after weaning from milk.

The water source (i.e., bucket or nipple) had no impact on the amount of water calves consumed before or after weaning. However, calves drank water more frequently from nipples than from buckets, although the lengths of water-drinking bouts were similar. Thus, the total daily duration spent drinking water was longer from nipples than from buckets, and calves received less water during one drinking bout from nipples than from buckets.

In addition, $75 \%$ of calves' drinking bouts were performed in atypical ways, such as by pressing the water nipple with their forehead and drinking the dripping

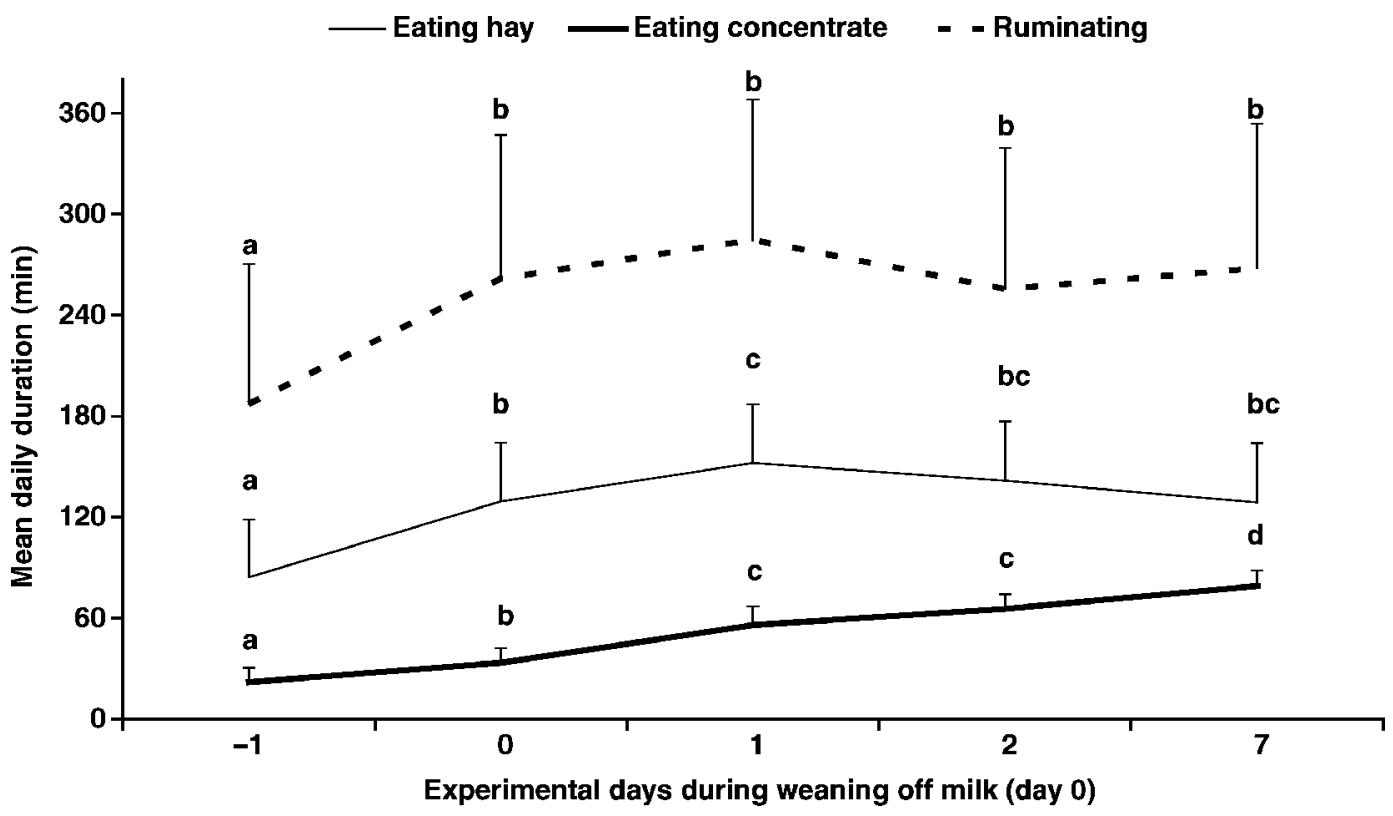

Figure 5. Effect of weaning off ad libitum acidified milk replacer on mean daily duration (min) spent by 2-mo-old calves eating concentrates, eating hay, or ruminating. Error bars lacking a common letter differ $(P<0.05)$. 


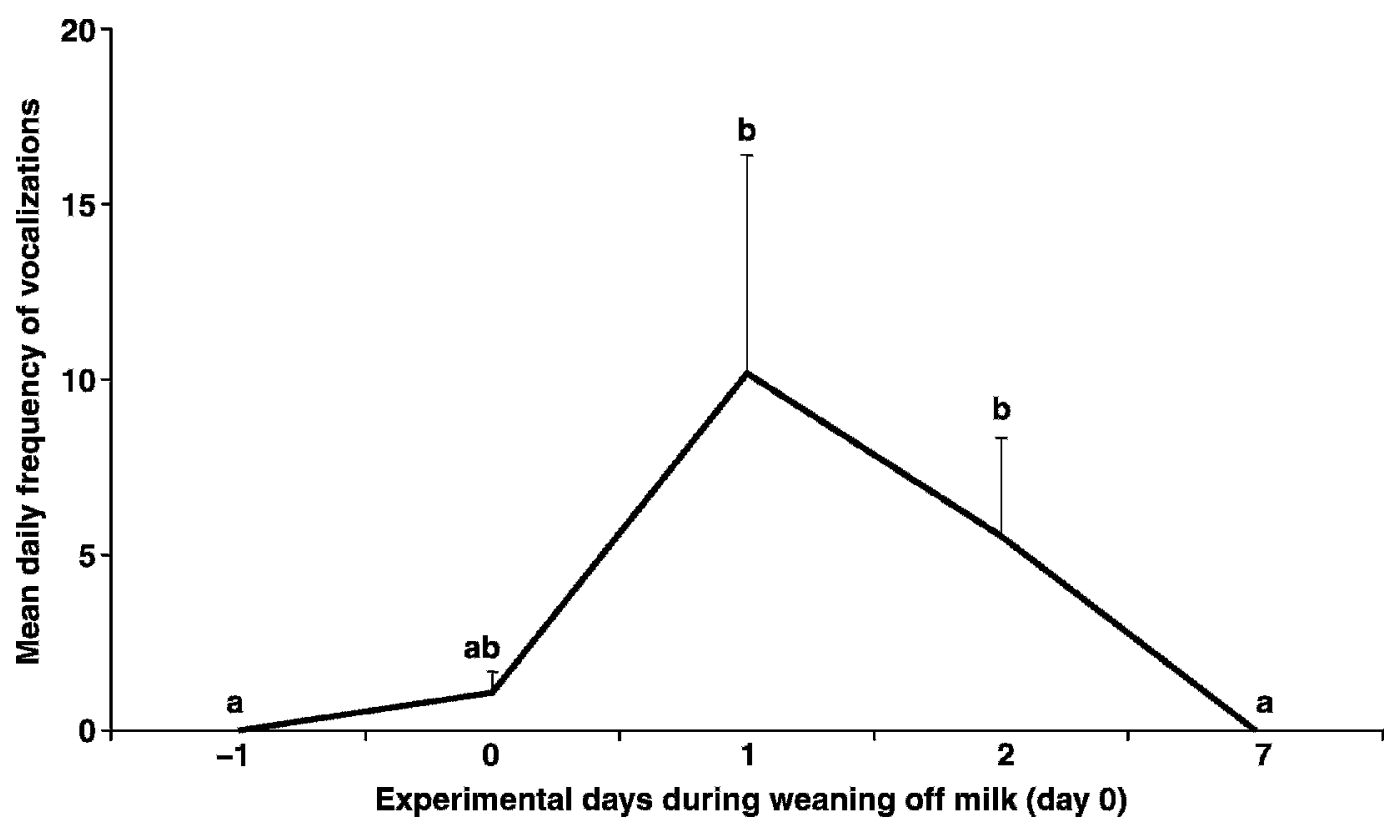

Figure 6. Effect of weaning off ad libitum acidified milk replacer on the vocalization of 2-mo-old calves. Error bars lacking a common letter differ $(P<0.05)$.

water. In addition, despite the preventing barrier, calves might have been able to consume some of the dripped water from the bucket. Thus, the water nipples may be difficult or inconvenient for the calves to use. Adult cows prefer to drink from a water trough instead of a stream (Sheffield et al., 1997) and from larger troughs instead of smaller ones (Machado Filho et al., 2004; Teixeira et al., 2006). However, more research is still needed on the use of water nipples for calves before and after weaning.

As expected, the calves consumed very little water (less than $0.4 \mathrm{~kg} / \mathrm{d}$ on average) when they had ad libitum access to acidified milk replacer, quite similar to the results of Richard et al. (1988). Calves in their study drank $0.45 \mathrm{~kg} / \mathrm{d}$ of water during the first $5 \mathrm{wk}$ of age. In the present study, no differences in water intake existed between the bucket and nipple. However, the variation between calves in water intake was great: between 0 and $3 \mathrm{~L} / \mathrm{d}$ during the week before weaning. Because the calves drank only little water, they possibly drank milk also for their thirst.

The postweaning ratio of water intake to total DMI was $4 \mathrm{~L} / \mathrm{kg}$ of DM, which is similar to the results of Quigley et al. (2006). The calves increased water intake in both groups rapidly after weaning. However, more research is needed on the effect of previous experience in using a water source (i.e., water nipple or bucket) on water-drinking behavior after weaning.

The large volume of milk consumed by the calves before weaning likely explains the low intake of water during this stage of the experiment. The calves drank an average of $13 \mathrm{~L}$ of acidified milk replacer per day. This was more than the $9.6 \mathrm{~L}$ of acidified whole milk in our previous experiment with group-housed calves receiving one teat per calf (Härtel et al., 2002), and in other experiments with ad libitum feeding in individual pens in which calves consumed 9 to $10 \mathrm{~L}$ of milk at 4 to 5 wk of age (Appleby et al., 2001; Jasper and Weary, 2002). In these studies, the milk used was whole milk, which had a higher energy content than the milk replacer used here. In addition, our individually housed calves had no competition for milk intake. Competition in group housing has reduced milk intake (von Keyserlingk et al., 2004). The differences might also be explained by different feeding methods. In Appleby et al. (2001), the calves consumed their largest meals when new, warm milk was provided. In our experiment, the temperature of the milk was always the same. In addition to satiating thirst, calves receiving milk ad libitum from the teat can satisfy their sucking need. Milk induces a sucking need (de Passillé et al., 1992), and calves may suck milk from the teat even when they are satiated (Hammell et al., 1988), which may explain the high milk intakes.

Water source did not affect concentrate intake. Before weaning, the calves fed milk ad libitum ate only small amounts of concentrates, a finding also reported by many others (e.g., Härtel et al., 2002; Jasper and Weary, 2002). After weaning, the calves in both groups increased their dry feed intake very rapidly, similar to the results of Jasper and Weary (2002). A positive correlation was 
present between water and concentrate intake postweaning, as seen in other studies with milk-fed calves (Kertz et al., 1984; Quigley et al., 2006).

The calves grew well and no differences existed between different water sources. Growth during the milkfeeding period was $1,120 \mathrm{~g} / \mathrm{d}$, which was similar to earlier work undertaken by our group on calves provided ad libitum access to acidified milk (Härtel et al., 2002). These growth rates are higher than in other work published on calves provided milk through ad libitum feeding systems (Richard et al., 1988; Appleby et al., 2001; Jasper and Weary, 2002). These differences may be due to our calves consuming higher daily portions of milk replacer, the longer rearing period used in our work, or both. The weight of calves decreased after weaning, consistent with a previous experiment with calves suckling their dams (Bar-Peled et al., 1997). However, calves' weight increased as soon as their DMI increased. This increase in live weight gain may be due in part to increased rumen contents (Forbes, 1995).

Before weaning, the calves' overall daily duration spent ruminating was shorter, and the dry feed intake was lower than in our previous experiment with restrictively fed (6 L of whole milk/d) 2-mo-old calves (Hepola et al., 2006). This may indicate that the calves fed milk ad libitum in this study were less well-developed ruminants than the calves in the previous experiment. However, after weaning, calves in this study quickly increased the time used for drinking water and eating concentrates, eating hay, or ruminating. No differences between different water sources were observed.

In this study, cross-sucking increased significantly after abrupt weaning and was probably the result of hunger. Cross-sucking is related to milk feeding and usually disappears after the milk-feeding period (Lidfors, 1993). This behavior is also related to eating, and nutritional undersupply during weaning can promote cross-sucking (Keil and Langhans, 2001; Roth et al., 2007). Calves in our study also exhibited a considerable number of other oral behaviors, such as licking structures or other calves (approximately 20\%), during the 2 $\mathrm{h}$ the calves were kept in the yard daily. This might be explained by exploration of the freshly littered yard, and also that the calves had only a restricted possibility for social contact during the rest of the day, and had no feed or water available in the yard.

In this experiment, the calves were abruptly weaned from a high amount of milk, which may have contributed to the negative responses of ad libitum feeding per se (i.e., low concentrate intake and less rumination during the milk-feeding time) and to the setback in growth and increased cross-sucking after weaning. Gradual weaning reduces many of the distress responses when calves are fed high milk volumes (Khan et al., 2007a,b).
Vocalization increased significantly on the first days after weaning, but decreased rapidly when the calves started to consume dry feeds. This increase was most probably due to hunger (Thomas et al., 2001), but calves could also have vocalized more to show frustration with unfamiliar feed (absence of milk). In addition, the calves could also have been reacting to the separation from the milk-feeding routine (Jasper et al., 2007).

\section{CONCLUSIONS}

Calves consumed very little water or dry feeds when they had ad libitum access to milk replacer. After weaning off milk, calves rapidly began to consume 8 to $9 \mathrm{~L}$ of water per day. The water source (i.e., open bucket or nipple) did not affect the amount of water consumed, but calves received water in smaller portions from water nipples than from open buckets. The calves also used water nipples in atypical ways (e.g., pressing with their foreheads). This might indicate difficulty in using the water nipples. However, more research is still needed on the use of water nipples for calves, before and after weaning, and on the effect of previous experience in using a water source (i.e., water nipple or bucket) on water-drinking behavior after weaning.

\section{ACKNOWLEDGMENTS}

This experiment was part of the project entitled "Behavior and Welfare of Cattle Housed in Large Groups" conducted by the Nordic Cattle Ethology Group in 2003 to 2006. We thank the Ministry of Agriculture and Forestry in Finland (Helsinki), the Walther Ehrström Foundation (Helsinki), and the University of Helsinki for funding. We are also grateful for help provided by Juha Suomi, Mia Väisänen, Meeri Mäki, Jenni Mönki, Vera Hakala, Sanni Heinonen, Kaisa-Mari Noponen, and the entire staff of the Viikki experimental barn, as well as Lauri Jauhiainen, and Tuomo Kokkonen for statistical advice, and Aila Vanhatalo for her comments on an earlier version of the manuscript.

\section{REFERENCES}

AOAC. 1995. Official Methods of Analysis. 16th ed. Assoc. Off. Anal. Chem., Arlington, VA.

Appleby, M. C., D. M. Weary, and B. Chua. 2001. Performance and feeding behaviour of calves on ad libitum milk from artificial teats. Appl. Anim. Behav. Sci. 74:191-201.

Bar-Peled, U., B. Robinzon, E. Maltz, H. Tagari, Y. Folman, I. Bruckental, H. Voet, H. Gacitua, and A. R. Lehrer. 1997. Increased weight gain and effects on production parameters of Holstein heifer calves that were allowed to suckle from birth to six weeks of age. J. Dairy Sci. 80:2523-2528.

Davis, C. L., and J. K. Drackley. 1998. The Development, Nutrition, and Management of the Young Calf. 1st ed. Iowa State Univ. Press, Ames. 
de Passillé, A. M. B., J. H. M. Metz, P. Mekking, and P. R. Wiepkema. 1992. Does drinking milk stimulate sucking in young calves? Appl. Anim. Behav. Sci. 34:23-36.

Drackley, J. K. 2005. Early growth effects on subsequent health and performance of dairy heifers. Pages 213-235 in Calf and Heifer Rearing. P. C. Garnsworthy, ed. Nottingham Univ. Press, Nottingham, UK.

Flower, F. C., and D. M. Weary. 2001. Effects of early separation on the dairy cow and calf: 2 . Separation at 1 day and 2 weeks after birth. Appl. Anim. Behav. Sci. 70:275-284.

Forbes, J. M. 1995. Voluntary Food Intake and Diet Selection in Farm Animals. CAB Int., Wallingford. UK.

Gottardo, F., S. Mattiello, G. Cozzi, E. Canali, E. Scanziani, L. Ravarotto, V. Ferrante, M. Verga, and I. Andrighetto. 2002. The provision of drinking water to veal calves for welfare purposes. J. Anim. Sci. 80:2362-2372.

Hammell, K. L., J. H. M. Metz, and P. Mekking. 1988. Sucking behaviour of dairy calves fed milk ad libitum by bucket or teat. Appl. Anim. Behav. Sci. 20:275-285.

Hepola, H., L. Hänninen, P. Pursiainen, V.-M. Tuure, L. Syrjälä-Qvist, M. Pyykkönen, and H. Saloniemi. 2006. Feed intake and oral behaviour of dairy calves housed individually or in groups in warm or cold buildings. Livest. Sci. 105:94-104.

Härtel, H., H. Hepola, N. Seppänen, R. Rauhala, S. Sankari, T. Soveri, H. Saloniemi, and L. Syrjälä-Qvist. 2002. Pikkuvasikoiden hapanmaitojuotto. Suomen Eläinlääkärilehti 2:84-89.

Jasper, J., and D. M. Weary. 2002. Effects of ad libitum milk intake on dairy calves. J. Dairy Sci. 85:3054-3058.

Jasper, J., M. Budzynska, and D. M. Weary. 2007. Weaning distress in dairy calves: Acute behavioural responses by limit-fed calves. Appl. Anim. Behav. Sci. doi:10.1016/j.applanim.2007.03.017.

Jensen, M. B. 2003. The effects of feeding method, milk allowance and social factors on milk feeding behaviour and cross-sucking in group housed dairy calves. Appl. Anim. Behav. Sci. 80:191-206.

Jensen, M. B. 2006. Computer-controlled milk feeding of group-housed calves: The effect of milk allowance and weaning type. J. Dairy Sci. 89:201-206.

Keil, N. M., and W. Langhans. 2001. The development of intersucking in dairy calves around weaning. Appl. Anim. Behav. Sci. 72:295-308.

Kertz, A. F., L. F. Reutzel, and J. H. Mahoney. 1984. Ad libitum water intake by neonatal calves and its relationship to calf starter intake, weight gain, feces score, and season. J. Dairy Sci. 67:2964-2969.

Khan, M. A., H. J. Lee, W. S. Lee, H. S. Kim, S. B. Kim, K. S. Ki, J. K. Ha, H. G. Lee, and Y. J. Choi. 2007a. Pre- and postweaning performance of Holstein female calves fed milk through step-down and conventional methods. J. Dairy Sci. 90:876-885.

Khan, M. A., H. J. Lee, W. S. Lee, H. S. Kim, K. S. Ki, T. Y. Hur, G. H. Suh, S. J. Kang, and Y. J. Choi. 2007b. Structural growth, rumen development, and metabolic and immune responses of Holstein male calves fed milk through step-down and conventional methods. J. Dairy Sci. 90:3376-3387.

Lidfors, L. 1993. Cross-sucking in group-housed dairy calves before and after weaning off milk. Appl. Anim. Behav. Sci. 38:15-24.
Machado Filho, L. C. P., D. L. Teixeira, D. M. Weary, M. A. G. von Keyserlingk, and M. J. Hötzel. 2004. Designing better water troughs: Dairy cows prefer and drink more from larger troughs. Appl. Anim. Behav. Sci. 89:185-193.

Maynard, L. A., J. K. Loosli, H. F. Hintz, and R. G. Warner. 1979. Animal Nutrition. 7th ed. Tata McGraw-Hill Publ. Co. Ltd., New Delhi, India.

MTT. 2006. MTT 2006 Rehutaulukot ja ruokintasuositukset (Feed tables and feeding recommendations). Agrifood Research Finland, Jokioinen, Finland. http://www.agronet.fi/rehutaulukot Accessed Jan. 28, 2007.

Ørskov, E. R. 1972. Reflex closure of the oesophageal groove and its potential application in ruminant nutrition. S. Afr. J. Anim. Sci. 2:169-176.

Quigley, J. D., T. A. Wolfe, and T. H. Elsasser. 2006. Effects of additional milk replacer feeding on calf health, growth, and selected blood metabolites in calves. J. Dairy Sci. 89:207-216.

Richard, A. L., A. J. Heinrichs, and L. D. Muller. 1988. Feeding acidified milk replacer ad libitum to calves housed in group versus individual pens. J. Dairy Sci. 71:2203-2209.

Roth, B. A., E. Hillmann, M. Stauffacher, and N. M. Keil. 2007. Improved weaning reduces cross-sucking and may improve weight gain in dairy calves. Appl. Anim. Behav. Sci. doi:10.1016/j.applanim.2007.06.007.

Sheffield, R. E., S. Mostaghimi, D. H. Vaughan, E. R. Collins, Jr., and V. G. Allen. 1997. Off-stream water sources for grazing cattle as a stream bank stabilization and water quality BMP. Am. Soc. Agric. Eng. 40:595-604.

Tanan, K. G., and J. R. Newbold. 2002. Nutrition of the dairy heifer calf. Pages 119-148 in Recent Advances in Animal Nutrition. P. C. Garnsworthy and J. Wiseman, ed. Nottingham Univ. Press, Nottingham, UK

Thomas, T. J., D. M. Weary, and M. C. Appleby. 2001. Newborn and 5 -week-old calves vocalize in response to milk deprivation. Appl. Anim. Behav. Sci. 74:165-173.

Teixeira, D. L., M. J. Hötzel, and L. C. P. Machado Filho. 2006. Designing better water troughs 2 . Surface area and height, but not depth, influence dairy cows' preference. Appl. Anim. Behav. Sci. 96:169-175.

von Bothmer, G. 1992. Verfahren und Ergebnisse zur Sauermilchtränke. KTBL-Schrift 352:83-92.

Van Soest, P. J., J. B. Robertson, and B. A. Lewis. 1991. Methods for dietary fiber, neutral detergent fiber, and nonstarch polysaccharides in relation to animal production. J. Dairy Sci. 74:3583-3597.

von Keyserlingk, M. A. G., L. Brusius, and D. M. Weary. 2004. Competition for teats and feeding behavior by group-housed dairy calves. J. Dairy Sci. 87:4190-4194.

von Keyserlingk, M. A. G., F. Wolf, M. Hötzel, and D. M. Weary. 2006. Effects of continuous versus periodic milk availability on behavior and performance of dairy calves. J. Dairy Sci. 89:2126-2131.

Yokoyama, M. T., and K. A. Johnson. 1988. Microbiology of the rumen and intestine. Pages 125-144 in The Ruminant Animal: Digestive Physiology and Nutrition. D. C. Church, ed. Reston/Prentice Hall, Englewood Cliffs, NJ. 